\title{
Restructured Fish Product from White Croacker (Micropogonias furnieri) Mince Using Microbial Transglutaminase
}

\author{
Alex Augusto Gonçalves ${ }^{1 *}$ and Marcelo Gonzalez Passos ${ }^{2}$ \\ ${ }^{1}$ Center of Water Resources Studies; Department of Civil and Resource Engineering; Dalhousie University; \\ Halifax; NS, B3J 1Z1; Canada. ${ }^{2}$ Departamento de Tecnologia Instituto de Ciência e Tecnologia de Alimentos; \\ Universidade Federal do Rio Grande do Sul; Porto Alegre - RS - Brasil
}

\begin{abstract}
This study aimed at determining the influence of three concentrations of commercial transglutaminase enzyme in restructured fillet of minced fish from white croacker (Micropogonias furnieri), one of the four marine species with notability in Brazil. The restructured fillet developed had advantages when compared to traditional fillet, such as absence of spine and less flavour intensity (washes cycles). Washing process for white croacker mince was compared with five clarification agents: water (control), phosphoric acid (H3PO4), sodium chloride (NaCl), calcium carbonate ( $\mathrm{CaCO} 3$ ) and sodium bicarbonate (NaHCO3). The higher quality product (whiteness) was obtained with calcium carbonate washes. Three concentrations (1.5, 1.0 and 0.5\%) of microbial transglutaminase MGTase (Active TG-B \%v/v and Active TG-BP \%w/w) were compared, in order to produce fish restructured product (boneless fillet). The concentration of $1.5 \%$ (both enzymes), produced better results. The restructured products were compared by sensory analysis and showed better sensory parameters (appearance, odour, flavour and texture) samples treated with Active TG-B (solution form).
\end{abstract}

Key words: Seafood, minced fish, white croacker, transglutaminase, restructured fish

\section{INTRODUCTION}

Fish is an important dietary constituent of several population groups and it has significant nutritional value, such as high quality proteins, vitamins, minerals and lipids, besides being the largest source of $\omega-3$ series polyunsaturated fatty acids (especially the EPA and DHA), which bring several benefits to human health (Belda and Pourchet-Campos, 1991; Badolato et al., 1994; Kim and Lall, 2000; Connor, 2000; Hardman, 2002; Limin, Feng and Jing, 2006; Visentainer et al., 2007).
The white croacker (Micropogonias furnieri) is a migratory euryhaline teleostean demersal fish found in the Atlantic Ocean from Northern Venezuela $\left(20^{\circ} \mathrm{N}\right)$ to the Gulf of St. Mathias $\left(41^{\circ} \mathrm{S}\right)$, Argentina (Vasconcellos and Haimovici, 2006; Berois et al., 2007). Over $50 \%$ of the total fisheries production in the region (south of Brazil) is supported by sciaenid species and the white croacker Micropogonias furnieri (Fig. 1) is one of the most abundant and important for local fisheries (Vasconcellos and Haimovici, 2006).

The composition of edible fish portion varies as a function of many factors, such as specie, sex,

*Author for correspondence: alaugo@gmail.com 
sexual maturity degree, size, place of capture, water temperature, type of feeding and season (Soccol and Oetterer, 2003). White croacker and minced showed the same variation during season (Table 1), as demonstrated by Badolato et al. (1994) and Luzia et al. (2003).
White croacker is captured more intensively in spring months (October to January) with medium size of $30 \mathrm{~cm}$ (Vasconcellos and Haimovici, 2006; Haimovici and Umpierre, 1996), but the fillet yield is low (31-36\%) and by-products with $10 \%$ of meat with high quality is not commercially used for mince production.

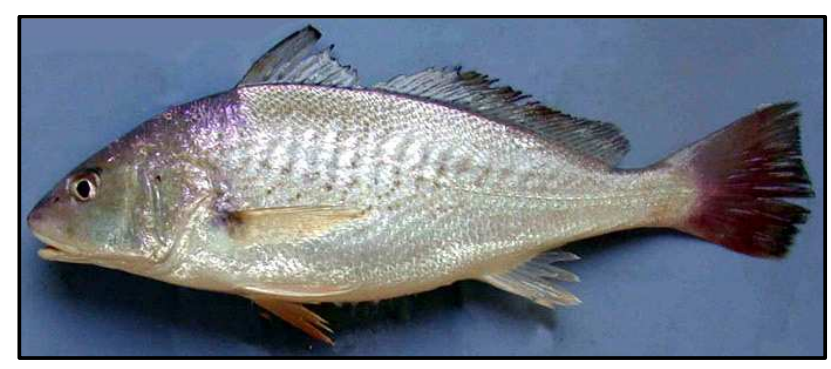

Figure 1 - White croacker (Micropogonias furnieri).

Table 1 - Chemical composition of white croacker during season

\begin{tabular}{|c|c|c|c|c|}
\hline \multicolumn{5}{|c|}{ Chemical composition $(\mathrm{g} / \mathrm{100g})$ of white croacker fillet } \\
\hline Season & Moisture & Ash & Lipid & Protein \\
\hline SU & 79.5 & 0.9 & 0.5 & 18.9 \\
\hline AU & 77.2 & 1.4 & 0.8 & 20.7 \\
\hline WI & 77.9 & 1.0 & 0.7 & 19.8 \\
\hline SP & 83.8 & 1.0 & 0.5 & 14.5 \\
\hline \multicolumn{5}{|c|}{ Chemical composition $(\mathrm{g} / \mathbf{1 0 0 g})$ of white croacker mince } \\
\hline Season & Moisture & Ash & Lipid & Protein \\
\hline SU & 79.7 & 1.4 & 1.4 & 16.7 \\
\hline $\mathrm{AU}$ & 77.0 & 1.3 & 1.3 & 20.1 \\
\hline WI & 81.6 & 0.7 & 1.1 & 16.2 \\
\hline SP & 83.1 & 0.1 & 0.6 & 16.5 \\
\hline
\end{tabular}

SU (Summer: December 21 to March 21); AU (Autumn: March 21 to June 21); WI (Winter: June 21 to September 21), SP (Spring: Sept. 21 to December 21).

In seafood processing, it is of great interest to maximize the yield of marketable products, including the developments of methods for restructuring low-value cuts and trimmings to improve their appearance, flavour and texture and to enhance the market value. Then an alternative process involves obtaining a fish paste by mechanical separation of the flesh and then preparing restructured fish products with high economic and nutritive value (Ramírez et al., 2007).

Restructuring yields fish products with high commercial value from different sources: noncommercial fish species, fish with size smaller than commercial (such as shrimp by-catch) and trimmings from fillets of commercial fish species. Although several methods of restructuring have been developed, the most commonly used include cutting, tumbling and massaging, with or without vacuum (Bruschi, 2001; Mira and LanferMarquez, 2005; Ramírez et al., 2007).

The production of transglutaminase by microorganisms makes it possible to apply this enzyme in a variety of food processes. Transglutaminase is an enzyme capable of catalyzing acyl-transfer reactions introducing covalent cross-links between the proteins as well as peptides and various primary amines, thereby improving the gel structure (Zhu et al., 1995; Jiang, Lev and Tsai, 1998; Uresti et al. 2003; 2004). Table 2 shows the application of microbial transglutaminase (MTGase) in seafood processing (Zhu et al., 1995; Piccolo, 2006). 


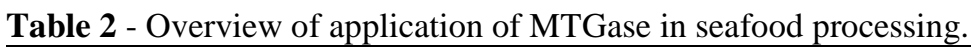

\begin{tabular}{ccc}
\hline Source & Product & Effect \\
\hline Fish & Fish paste & Improved texture and appearance \\
Krill & Krill paste & Improved texture \\
Fish & Fishburguer & Improved elasticity, texture, taste and flavour \\
Collagens & Shark-fin imitation & Imitation of delicious food \\
\hline
\end{tabular}

Nowadays, a commercial microbial transglutaminase (MTGase) is employed to improve the mechanical and textural properties of different protein foods, including surimi products (Barrera et al., 2002). MTGase catalyzes the same reaction as endogenous transglutaminase, but the first is non-calcium dependent and shows lower deamidation affinity than endogenous transglutaminase of fish (Ohtsuka et al., 2001; Sato et al., 2001). Several studies have been conducted to determine the optimal conditions for using MTGase in restructured fish products (Zhu et al., 1995; Téllez-Luis et al., 2002; Uresti et al., 2004; Ramírez et al., 2007).

The objective of this work was to determine the feasibility of using microbial transglutaminase (MTGase) as binding agent to prepare a restructured fish products from white croacker mince with acceptable sensorial characteristics.

\section{MATERIAL AND METHODS}

\section{Raw material}

Fresh white croacker (Micropogonias furnieri) was obtained directly from the market, thoroughly rinsed with cold tap water, stored in ice and transported to the laboratory immediately in less than one hour, where it was washed, weighed, headed, gutted and filleted manually. Skin and bone were removed manually and fillets were washed and weighed. Fillets were grounded with 4 $\mathrm{mm}$ diameter perforations to obtain a homogeneous mince, according to Jesus et al (2001). The obtained mince was maintained at refrigeration temperature until the clarification process.

\section{Minced fish clarification process}

Mince washing process was compared with five clarification agents: water (control), phosphoric acid $\left(\mathrm{H}_{3} \mathrm{PO}_{4}\right)$, sodium chloride $(\mathrm{NaCl})$, calcium carbonate $\left(\mathrm{CaCO}_{3}\right)$ and sodium bicarbonate $\left(\mathrm{NaHCO}_{3}\right)$. For each treatment, fish mince samples $(50 \mathrm{~g})$ were mixed with $150 \mathrm{ml}$ of clarification solution (Table 3) in a mince/clarification solutions ratio of $1: 3$, with constant agitation (Gomes et al., 1994; Cândido; Nogueira; Sgarbieri, 1998; Barreto and Beirão, 1999; Tenuta and Jesus, 2003). For each step, the concentration diminished and the third step samples were washed only with distilled water.

After three washing cycle at $10^{\circ} \mathrm{C}$ for 10 minutes for each treatment, all the samples were followed by manually dewatering employing cheesecloth as filtering material (Barrera et al., 2002) and pressed to remove the excess water, weighed, packed and stored at $4^{\circ} \mathrm{C}$ (Simões et al., 1998; MonterreyQuintero and Sobral, 2000; Mira and LanferMarquez, 2005).

Table 3 - Washing cycles.

\begin{tabular}{cccc}
\hline Clarification agents & STEP I & STEP II & STEP III \\
\hline Water & $150 \mathrm{~mL}$ & $150 \mathrm{~mL}$ & $150 \mathrm{~mL}$ \\
$\mathrm{H}_{3} \mathrm{PO}_{4}$ & $150 \mathrm{~mL}(0.05 \%)$ & $150 \mathrm{~mL}(0.025 \%)$ & $150 \mathrm{~mL}(0 \%)$ \\
$\mathrm{CaCO}_{3}$ & $150 \mathrm{~mL}(0.5 \%)$ & $150 \mathrm{~mL}(0.25 \%)$ & $150 \mathrm{~mL}(0 \%)$ \\
$\mathrm{NaCl}$ & $150 \mathrm{~mL}(0.5 \%)$ & $150 \mathrm{~mL}(0.25 \%)$ & $150 \mathrm{~mL}(0 \%)$ \\
$\mathrm{NaHCO}_{3}$ & $150 \mathrm{~mL}(0.5 \%)$ & $150 \mathrm{~mL}(0.25 \%)$ & $150 \mathrm{~mL}(0 \%)$ \\
\hline
\end{tabular}

\section{Preparation of restructured product}

The clarified minced was examined to make sure that it was free of bones and then "glued" together using a food-grade enzyme produced by Ajinomoto Co (Ajinomoto, 2007). The binding agent used was a commercial transglutaminase
(MTGase), Activa TG-B diluted in distilled water $(1: 5, w / v)$ and TG-BP (dry form), which was separated from a culture of Streptoverticillium mobaraense.

All enzymes were tested in three concentrations reported as a commercial concentration $(0.5,1.0$ 
and $1.5 \%$ ) dissolved in distilled water prior to being mixed into the mince and compared with a control sample (without enzyme), according to Piccolo (2006). Control product was obtained without the addition of MTGase.

The minced fish treated by mTGase was then formatted in a cylindrical sample of $3.5 \mathrm{~cm}$ diameter and $1 \mathrm{~cm}$ length by pressure and stored at $10^{\circ} \mathrm{C}$ for 160 minutes previously calculated in preliminary experiments, considering the temperature profile of the MTGase activity (Ajinomoto, 2007).

\section{Sensorial analysis}

Quantitative descriptive analysis (QDA) was performed with the presence of a staff of 30 nontrained panellists who registered the sensory attributes: appearance, flavour, taste and texture (unstructured line scale of $9 \mathrm{~cm}$ ) according to Dutcosky (1996). The test was accomplished in a sensory panel room where each person received three samples of hot fried restructured products for evaluation.

Statistical analysis was performed using Statistica for Windows (StatSoft Release 6.0) and ANOVA test were used to determine significantly differences $(\mathrm{p}<0.05)$ among the treatments.

\section{RESULTS AND DISCUSSION}

\section{Minced fish production}

The filleting yield was $32.1 \%$, which was lower than yields of $36 \%$ obtained by Bruschi (2001) for the same specie. This filleting yield variability could be a function of several aspects, such as fish size, filleting system (mechanical or manual), practice of fillet workers, which contributed to an increase and/or decrease in the percentage of meat withholding carcass (Bykowski and Dutkiewicz, 1996; Souza, 2002). The process could be optimized using Meat Recovery and Meat Separation Machinery, reaching a percentage around $50 \%$ as obtained by Bykowski and Dutkiewicz (1996) and Mira and Lanfer-Marques (2005).

\section{Minced fish clarification process}

The most important step of mince and/or surimi processing to ensure the maximum gelling, as well as colorless and odourless is efficient washing (Park and Morrissey, 2000). According to Hultin and Kelleher (2000), the addition of alkali in the surimi wash water produced a higher quality product than just using water. Various concentrations of sodium bicarbonate may be added in one or more of the wash steps to increase $\mathrm{pH}$. Sodium chloride is also sometimes added. Some authors considered that mince washing was significant in reducing the water soluble components (heme-pigments), improving the textural quality (Lin and Park, 1996; Lee et al, 1998; Tenuta and Jesus, 2003).

Several studies have demonstrated chlorine water as a better agent for clarifying the minced fish and to improve its safety (Monterrey-Quintero and Sobral, 2000; Jesus et al., 2001; Mira and LanferMarquez, 2005). In this study (Fig. 2) all the clarification agents used showed positive results, i.e., there was bleaching (whiteness) when compared to non-washed minced. Moreover, phosphoric acid and calcium carbonate had higher whiteness results.

The result of calcium carbonate was considered better because the washed mince was more homogeneous (doughy) when compared with phosphoric acid (mass with granular appearance). Another reason that contributed to this choice was the lower price of $\mathrm{CaCO}_{3}$ when compared to $\mathrm{H}_{3} \mathrm{PO}_{4}$ as well to avoid the contact with acids that would always be a factor of risk to personal safety and equipment.

The washing process has the secondary goal, i.e., removing the natural components of the minced fish, such as proteins soluble in water, blood and other components (heme pigments), which could accelerate the deterioration (lipid oxidation and microorganisms) during the storage of low temperatures. Another interesting result was that washed minced fish presented an intense characteristic aroma even after freezing and thawing. The yield reached in this process was $98.13 \%$, which was considered satisfactory.

\section{Preparation of restructured product}

The $\mathrm{pH}$ result after wash cycles with $\mathrm{CaCO} 3$ was higher ( $\mathrm{pH}$ 10) than the range of MTGase activity ( $\mathrm{pH}$ 5-8), but in preliminary study, the restructuring was found. It has been suggested that gelation is improved after this type of washing process because the solubility of the sarcoplasmic proteins is increased and there is a decreased rate of denaturation as the muscle $\mathrm{pH}$ is increased (Hultin and Kelleher, 2000). The restructuring probably can be optimized with a simple reduction in concentrations of $\mathrm{CaCO}_{3}$ or with the addition of 
another washing cycle with water, though these suggestions would need to be proven through new trials and future studies.

According to Lee et al (1998), washed mince must be titrated at $\mathrm{pH} 8.0$ for the best condition of MTGase activity. The adjustment of $\mathrm{pH}$ in the range of high enzyme activity ( $\mathrm{pH} 5-8$ ) probably might entail a reduction in the cost production, because the efficiency of the restructuring would be related directly to enzyme activity.

Figure 3 shows the production steps of restructured products using the enzymes (MTGase), Activa TG-B (solution form) and TGBP (dry form).

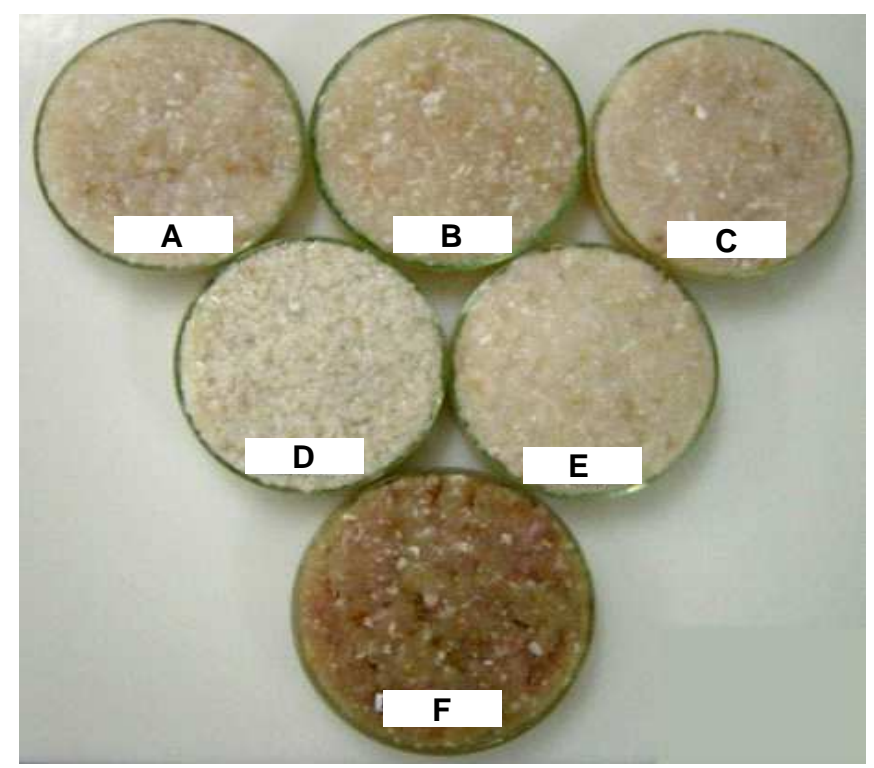

Figure 2 -Washing steps in minced fish clarification process $\left(\mathrm{A}: \mathrm{NaCl} ; \mathrm{B}: \mathrm{NaHCO}_{3}, \mathrm{C}\right.$ : Water (control); D: $\mathrm{H}_{3} \mathrm{PO}_{4}, \mathrm{E}: \mathrm{CaCO}_{3}$ and $\mathrm{F}$ : non-washed mince).

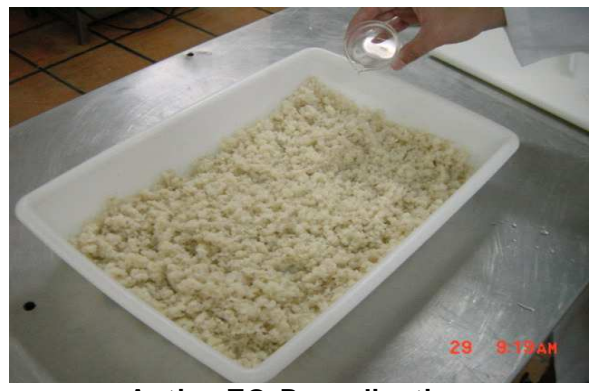

Activa TG-B application

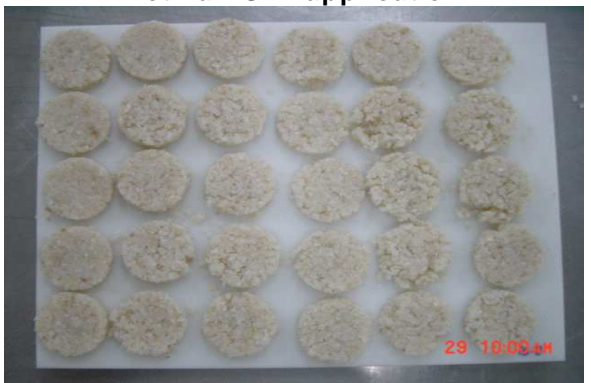

Restructured product with TG-B

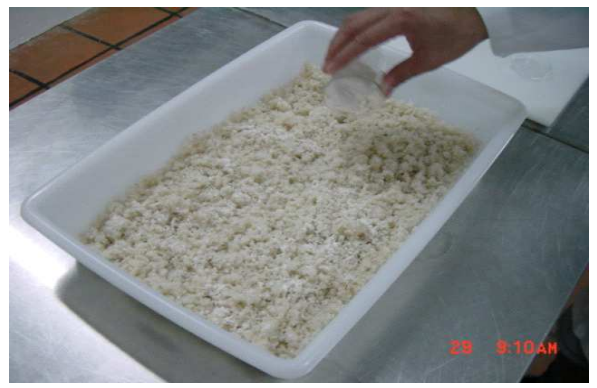

Activa TG-BP application

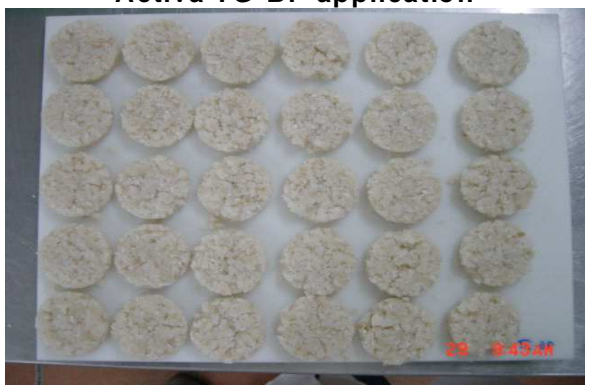

Restructured product with TG-BP

Figure 3 - Restructured product steps. 
The structure formed by pressure during fish product forming with MTGase showed the importance of this procedure during MTGase activity. When pressure is released, the protein is restructured initially by hydrogen bonding and later by MTGase activity (Montero, 2005).

Figure 4 shows the comparison of the MTGase concentrations used before and after frying samples. The $1.5 \%$ concentrations achieved the best results before and after frying, showing a improvement of restructuring with increasing MTGase concentration, as obtained by Uresti et al. (2003); however, other concentrations also resulted a small restructuring. The MTGase (TG-B and TGBP) concentration of $1.5 \%$ was chosen the for sensory analysis. Uresti et al. (2004) and Ramírez et al. (2007) obtained restructuring using MTGase associated with milk protein proving the property of restructuring in meat products with low salt concentration.

As mentioned previously, the fish characteristic aroma was intense even after thawing (before the use of the transglutaminase) and the mince color remained attractive what was considered satisfactory.

The results of this stage through visual examination showed that MTGase Activa TG-BP sample had superior characteristics on the restructuring when compared to MTGase Activa TG-B, which should be supported by sensory analysis. A problem encountered in this stage was an excessive drip loss after thawing (lower water holding capacity), which led difficulties for final product formatting. To improve this process, a mixture of phosphates could be used (Hultin and Kelleher, 2000).

Several studies have been used to improve the mechanical and functional properties of restructured fish products, dairy proteins, salt at low concentrations, phosphate, starch and hydrocolloids, such as carrageenan (Barreto and Beirão, 1999; Uresti et al, 2004; Gonçalves, 2005; Ramírez et al. 2007).

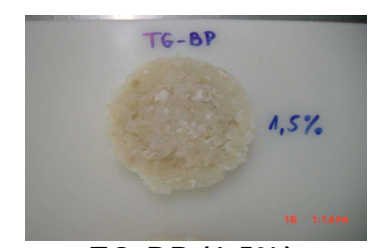

TG-BP $(1,5 \%)$

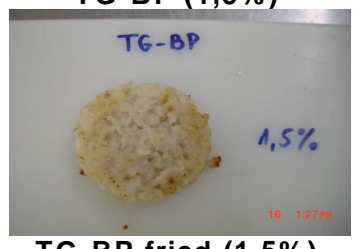

TG-BP fried $(1,5 \%)$
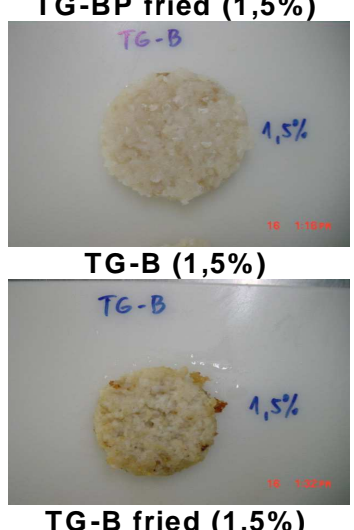

TG-B fried (1,5\%)

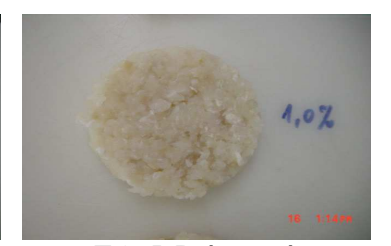

TG-BP (1,0\%)

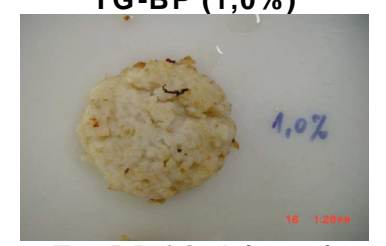

TG-BP fried $(1,0 \%)$

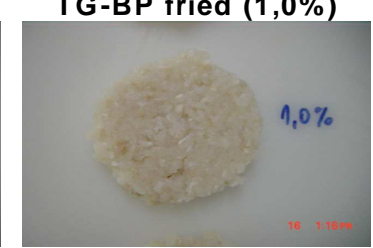

TG-B $(1,0 \%)$

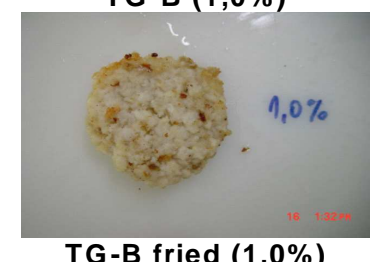

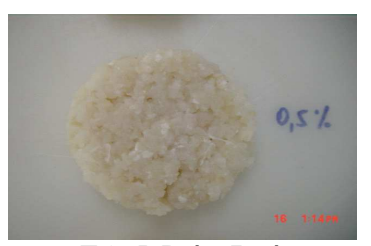

TG-BP $(0,5 \%)$
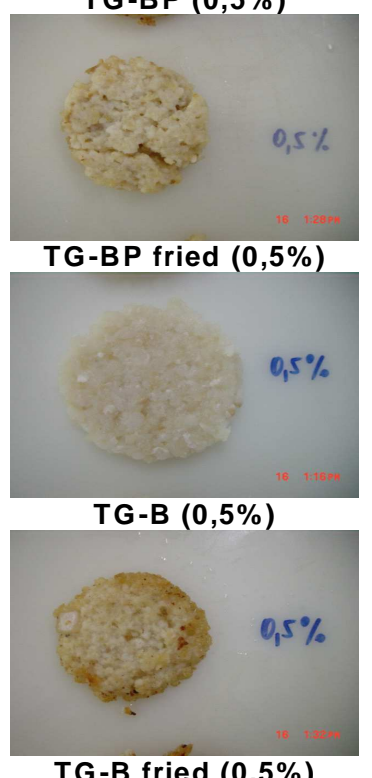

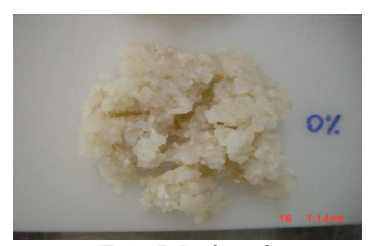

TG-BP (0\%)

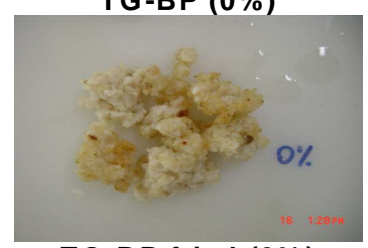

TG-BP fried (0\%)

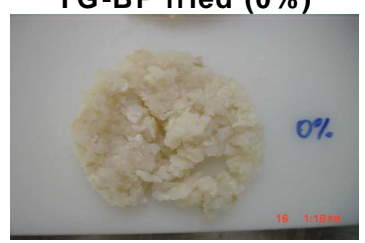

TG-B (0\%)

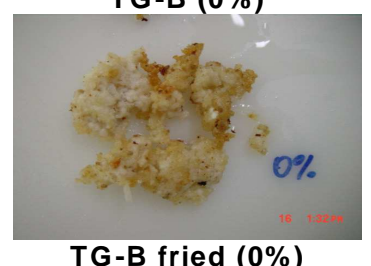

Figure 4 - Different concentrations of MTGase before and after frying. 


\section{Sensorial analysis}

Both the samples were approved by panelists and significant difference between the samples MTGase Activa TG-B (solution form) and TG-BP (dry form) (Table 4) were observed.
It was interesting note that in all the sensorial parameters evaluated the sample treated with MTGase in solution form (TG-B) was superior to powder form (TAG-BP), which indicated its use to make a better restructured product.

Table 4 - Sensorial parameters of restructured product (mean \pm Std.Dv).

\begin{tabular}{ccc}
\hline Sensorial Parameters & MTGase TG-B & MTGase TG-BP \\
\hline APPEARANCE & $6,33 \pm 1,15 \mathrm{a}$ & $5,82 \pm 0,84 \mathrm{~b}$ \\
FLAVOUR & $5,74 \pm 1,24 \mathrm{a}$ & $5,24 \pm 0,83 \mathrm{~b}$ \\
TASTE & $5,13 \pm 0,83 \mathrm{a}$ & $4,22 \pm 0,34 \mathrm{~b}$ \\
TEXTURE & $5,78 \pm 0,69 \mathrm{a}$ & $4,81 \pm 0,31 \mathrm{~b}$ \\
\hline
\end{tabular}

Different letters in the line mean significantly different $(\mathrm{p}<0,05) ; \mathrm{n}=30$.

\section{CONCLUSIONS}

It could be concluded that the five substances tested as clarification agents $\left(\mathrm{H}_{2} \mathrm{O}, \mathrm{H}_{3} \mathrm{PO}_{4}, \mathrm{NaCl}\right.$, $\mathrm{CaCO}_{3}, \mathrm{NaHCO}_{3}$ ) achieved positive results when compared to non-washed mince, with further clarification (more white mince) by $\mathrm{CaCO}_{3}$ and $\mathrm{H}_{2} \mathrm{PO}_{4}$, but the $\mathrm{CaCO}_{3}$ was chosen as the best agent for clarification to present better uniformity, lower cost and better environmental security. Probably $\mathrm{pH}$ values of washed mince with $\mathrm{CaCO}_{3}$ $(\mathrm{pH} 10)$ remained above the range of optimal enzyme activity (5-8). However, more studies are needed to determine the effect of level of $\mathrm{CaCO}_{3}$ addition on the restructuring properties of MTGase.

In developing the restructured product, results were satisfactory for all the concentrations of transglutaminase $(1.5,1.0$ and $0.5 \%)$ in both the treatments (MTGase TAG-B and TAG-BP). However, the samples with higher concentration $(1.5 \%)$ showed best restructuring. The results of the comparison of sensory analysis for the treatment MTGase Active TG-B and TG-BP showed that both the restructured products were approved but TAG-B was better than TAG-BP.

\section{ACKNOLEDGEMENTS}

The authors gratefully acknowledge the Ajinomoto Interamericana Ind. e Com. Ltda. for kind support during the practical execution of this work.

\section{RESUMO}

Este estudo teve como objetivo determinar a influência de três concentrações de enzima transglutaminase comercial em filés reestruturado a partir de polpa de corvina (Micropogonias furnieri), uma das quatro espécies marinhas notáveis no Brasil. $\mathrm{O}$ filé reestruturado desenvolvido tem vantagens quando comparado aos filés tradicionais, tais como, a ausência da espinhas e sabor menos intenso (ciclos de lavagens). O processo de lavagem da polpa de corvina foi comparado com cinco agentes clarificantes: água (controle), ácido fosfórico $\left(\mathrm{H}_{3} \mathrm{PO}_{4}\right)$, cloreto de sódio $(\mathrm{NaCl})$, carbonato de cálcio $\left(\mathrm{CaCO}_{3}\right)$ e bicarbonato de sódio $\left(\mathrm{NaHCO}_{3}\right)$. $\mathrm{O}$ produto de qualidade superior (mais branco) foi obtido com a lavagem com carbonato de cálcio. Três concentrações $(1,5 \%, 1,0 \%$ e $0,5 \%)$ de transglutaminase microbiana (Activa TG-B \% v/v e Activa TG-BP $\%$ p/p) foram comparadas a fim de produzir o produto reestruturado (filé sem espinha). A concentração de $1,5 \%$ (ambas as enzimas) produziu melhores resultados. Os produtos reestruturados foram comparados através de análise sensorial, e apresentaram melhores parâmetros sensoriais (aparência, odor, sabor e textura), as amostras tratadas com Activa TG-B (forma de solução). 


\section{REFERENCES}

Ajinomoto (2007), Activa. Disponível em: <http://www.ajinomoto.com.br/2007/index.php?area= pindustriaandsub=alimentosebebidasanditem $=$ enzima s.>

Badolato, E.S.G.; Carvalho, J.B. de; Amaral Mello, M.R.P.; Tavares, M.; Campos, N.C.; Aued-Pimentel, S. and Morais, C. (1994), Composição centesimal, de ácidos graxos e valor calórico de cinco espécies de peixes marinhos nas diferentes estações do ano. Revista do Instituto Adolfo Lutz, 54 (1): 27-35.

Barrera, A.M.; Ramírez, J.A.; González-Cabriales, J.J. and Vázquez, M. (2002), Effect of pectins on the gelling properties of surimi from silver carp. Food Hydrocolloids, 16, 441-447.

Barreto, P.L.M. and Beirão, L.H. (1999), Influência do amido e carragena nas propriedades texturais de surimi de tilápia (Oreochomis sp.). Ciência $e$ Tecnologia de Alimentos, 19 (2), 183-188.

Belda, M.C.R.; Pourchet-Campos, M.A. (1991), Ácidos graxos essenciais em nutrição: uma visão atualizada. Ciência e Tecnologia de Alimentos, 11 (1), 5-35.

Berois, N.; Arezo, M.J.; Chalar, C.; Brauer, M.M. and Barros, C. (2007), Ultrastructure and protein composition of the oocyte envelope in the whitemouth croacker (Micropogonias furnieri, Desmarest, 1823, Sciaenidae, Perciformes). Journal of Applied Ichthyology, 23, 34-39.

Bruschi, F.L.F. (2001), Rendimento, composição química e perfil de ácidos graxos de pescados e seus resíduos: uma comparação. Monografia (Graduação), Universidade do Vale do Itajaí, Centro de Ciências Tecnológicas da Terra e do Mar, Curso de Oceanografia, Itajaí, 65 p.

Bykowski, P. and Dutkiewicz, D. (1996), Freshwater fish processing and equipment in small plants. FAO Fisheries Circular, $\mathrm{N}^{\circ}$ 905. Rome, FAO, 59 p.

Cândido, L.M.B.; Nogueira, A.K. and Sgarbieiri, V.C. (1998), Propriedades funcionais de concentrados protéicos de pescado preparados por vários métodos. Journal Food Technology, Campinas, 1 (1/2), 77-89.

Connor, W.E. (2000), Importance of n-3 fatty acids in health and disease. American Journal of Clinical Nutrition, 71 (1), 171S-5S.

Dutcosky, S.D. (1996), Análise Sensorial de Alimentos. Curitiba: Champagnat, 123p.

Gomes, J.C.; Bianchini, M.G.A.; Pereira, C.A.S.; Coelho, D.T. and Costa, P.M.A. (1994), Processamento e caracterização do surimi de peixe de água doce. Ciência e Tecnologia de Alimentos, 14 (2), 226-237.

Gonçalves, A.A. (2005), Estudo do processo de congelamento do camarão associado ao uso do aditivo fosfato. Tese de Doutorado, Universidade
Federal do Rio Grande do Sul, Porto Alegre, Brasil, $170 \mathrm{p}$.

Haimovici, M. and Umpierre, R.G. (1996), Variaciones estacionales en la estructura poblacional del efectivo pesquero da corvina blanca Micropogonias furnieri (Desmarest, 1823) en el extremo sur de Brasil. Atlântica, 18, 179-203.

Hardman, W.E. (2002), Omega-3 fatty acids to augment cancer therapy. American Society for Nutritional Sciences, 132, 3508S-3512S.

Hultin, H.O. and Kelleher, S.D. (2000), Surimi processing from dark muscle fish. In: Surimi and Surimi Seafood (Park, J. W. ed.). New York: Marcel Dekker Inc., Chap. 3, p. 59-77.

Jesus, R.S.; Lessi, E. and Tenuta-Filho, A. (2001), Estabilidade química e microbiológica de "minced fish" de peixes amazônicos durante o congelamento. Ciência Tecnologia Alimentos, 21 (2), 144-148.

Jiang, S.T.; Leu, S.Z. and Tsai, G.J. (1998), CrossLinking of mackerel surimi actomyosin by microbial transglutaminase and ultraviolet irradiation. Journal of Agricultural and Food Chemistry, 46, 5278-5282.

Kim, J.-D. and Lall, S.P. (2000), Amino acid composition of whole body tissue of Atlantic halibut Hippoglossus hippoglossus, yellowtail flounder Pleuronectes ferruginea and Japanese flounder Paralichthys oliÍaceus. Aquaculture, 187, 367-373.

Lee, S.M.; Chiang, C.F. and Pan, B.S. (1988), Occurrence of transglutaminase in grey mullet (Mugil cephalus) muscle and it's effect on minced fish product. Journal of Food Biochemistry, 22, 475-487.

Limin, L.; Feng, X. and Jing, H. (2006), Amino acids composition difference and nutritive evaluation of the muscle of five species of marine fish, Pseudosciaena crocea (large yellow croacker), Lateolabrax japonicus (common sea perch), Pagrosomus major (red seabream), Seriola dumerili (Dumeril's amberjack) and Hapalogenys nitens (black grunt) from Xiamen Bay of China. Aquaculture Nutrition, 12, 53-59.

Lin, T.M. and Park, J.W. (1996), Extraction of proteins from Pacific Whiting mince at various washing conditions. Journal of Food Science, 61 (2), 432-438.

Luzia, L.A.; Sampaio, G.R.; Castellucci, C.M.N. and Torres, E.A.F.S. (2003), The influence of season on the lipid profiles of five commercially important species of Brazilian fish. Food Chemistry, 83: 93-97.

Mira, N.V.M. and Lanfer-Marquez, U.M. (2005), Avaliação da composição centesimal, aminoácidos e mercúrio contaminante de surimi. Ciência $e$ Tecnologia de Alimentos, 25 (4), 665-671.

Montero, P.; López-Caballero, M.E.; Pérez-Mateos, M.; Solas, M.T. and Gómez-Guillén, M.C. (2005), Transglutaminase activity in pressure-induced gelation assisted by prior setting. Food Chemistry, 90, 751-758.

Monterrey-Quintero, E.S. and Sobral, P.J.A. (2000), Preparo e caracterização de proteínas miofibrilares de 
tilápia-do-nilo para elaboração de biofilmes. Pesquisa Agropecuária Brasileira, 35 (1), 179-189.

Ohtsuka, T.; Umezawa, Y.; Nio, N. and Kubota, K. (2001), Comparison of deamidation activity of transglutaminases. Journal of Food Science, 66 (1), $25-29$.

Park, J.W. and Morrissey, M.T. (2000), Manufacturing of surimi from light muscle fish. In: Surimi and Surimi Seafood (Park, J. W. ed.). New York: Marcel Dekker Inc., Chap. 2, p. 23-58.

Piccolo, K.C. (2006), Avaliação do efeito da enzima transglutaminase no processo de produção de requeijão cremoso. Dissertação (Mestrado), Escola de Engenharia Mauá do Centro Universitário do Instituto Mauá de Tecnologia, São Caetano do Sul, SP.

Ramírez, J.A.; Ángel, A.D.; Uresti, R.M.; Velásquez, G. and Vázquez, M. (2007), Low salt restructured products from striped mullet (Mugil cephalus) using microbial transglutaminase or whey protein concentrate as additives. Food Chemistry, 102, 243249.

Sato, K.; Tanaka, C.; Kotaru, M.; Yoshikawa, H.; Kawabata, M.; Ikeuchi, T.; Sato, K.; Nakamura, Y. and Ohtsuki, K. (2001), Different arrangement of $\varepsilon$ ( $\gamma$-Glutamyl)lysine cross-linking in Alaska Pollock (Theragra chalcogramma) surimi proteins by Streptoverticillium and endogenous transglutaminases during suwari process. Journal of Food Biochemistry, 25, 397-409.

Simões, D. R. S.; Pedroso, M. A.; Augusto Ruiz, W. and Almeida, T. L. (1998), Hambúrgueres formulados com base protéica de pescado. Ciência $e$ Tecnologia de Alimentos, 18 (4), 414-420.

Soccol, M.C.H. and Oetterer, M. (2003), Seafood as functional food. Brazilian Archives of Biology and Technology, 48 (3), 443-454.

Souza, M.L.R. (2002), Comparação de seis métodos de filetagem, em relação ao rendimento de filé e de subprodutos do processamento da Tilápia-do-Nilo
(Oreochromis niloticus). Revista Brasileira de Zootecnia, 31 (3), 1076-1084.

Téllez-Luis, S.J.; Uresti, R.M.; Ramírez, J.A. and Vázquez, M. (2002), Low-salt restructured fish products using microbial transglutaminase. Journal of Food Science and Agriculture, 82, 953-959.

Tenuta $\mathrm{F}^{\circ}$, A. and Jesus, R.S. (2003), Aspectos da utilização de carne mecanicamente separada de pescado como matéria-prima industrial. Boletim da SBCTA, 37 (2), 59-64.

Uresti, R.M.; Ramírez, J.A. ; López-Arias, N. and Vázquez, M. (2003), Negative effect of combining microbial transglutaminase with low methoxyl pectins on the mechanical properties and colour attributes of fish gels. Food Chemistry, 80, 551-556.

Uresti, R.M.; Téllez-Luis, S.J.; Ramírez, J.A.; Vázquez, M. (2004), Use of dairy proteins and microbial transglutaminase to obtain low-salt fish products from filleting waste from silver carp (Hypophthalmichthys molitrix). Food Chemistry, 86, 257-262.

Visentainer, J.V.; Noffs, M.D.; Carvalho, P.O.; Almeida, V.V.; Oliveira, C.C. and Souza, N. E. (2007), Lipid content and fatty acid composition of 15 marine fish species from the southeast coast of Brazil. Journal of the American Oil Chemists' Society, 84, 543-547.

Vasconcellos, M. and Haimovici, M. M. (2006), Status of white croacker Micropogonias furnieri exploited in southern Brazil according to alternative hypotheses of stock discreetness. Fisheries Research, 80: 196-202.

Zhu, Y.; Rinzema, A. and Tramper, J. (1995), Microbial trasglutaminase - a review of its production and application in food processing. Applied Microbiology and Biotecnology, 44, 277-282.

Received: February 26, 2008; Revised: August 14, 2008; Accepted: November 04, 2009. 